\title{
Development Strategy of Human Resource Management For Millennial Generation
}

\author{
Novi Febriyanti ${ }^{1 *}$ and A. Fikri Amiruddin Ihsani ${ }^{2}$ \\ ${ }^{1,2}$ Universitas Islam Negeri Sunan Ampel, Surabaya, Indonesia
}

\begin{abstract}
Development strategy of human resource management for millennial generation is a step purposed at producing superior individuals who have characteristics and abilities that can compete and have a sale value that can be relied on either in a company or organization. The purposes of this study was to answering the formulation of problems regarding the characteristics of millennial generation related to work culture and human resource development strategies for millennial generation. The research method used descriptive qualitative by library research or literature study. The results of this study prove that the strategy being carried out is a way to improve the ability of every individual likes a training responsibility, intensive learning, behavior modification, immediate information, learning practice and patterns. Supporting sustainable factors are ability, motivation and opportunity.
\end{abstract}

Keywords: Development Strategy, Human Resource Management, Millennial Generation

\section{Introduction}

The era of globalization is characterized by technological developments and information flows very fast. This causes the company or organization to understand and develop reliable resources to be able to compete in a competitive business environment. One resource in the basic activities of a company or organization is human resources (HR). Human resource is the power that comes from in humans. This power called interpreted manpower expertise or skills possessed by every human (Safri, 2019). Human resorce is the ability within humans to create their status as social beings who can adapt and adjust and are able to regulate themselves and all the potentials contained in nature towards the achievement of the welfare of life in a balanced and sustainable order. The ability, expertise and creativity will not be optimal if it is not sharpened and developed with the development of human resources (Farchan, 2018).

Human resource development is one of the important activities in the company or organization, where employees and companies work together in balance for the company's existence. Human resource development can be done in several forms, usually each company has different characteristics according to the situation and also the needs of the company. This is usually done by increasing skills with training and coaching, increasing employee knowledge by means of socialization and education as well as various other ways. Human resource development is an effort with the purpose of improving employee skills through education, training and final development in order to carry out duties as employees and have a long-term cycle (Miftahuddin et al, 2018). Human resource development is usually carried out through work programs in the personnel management department or also called Human Resource Development (HRD).

Planning a good human resource development strategy in developing strategies to produce quality human resources is a necessity that is the duty of every company or organization leader to achieve the goals set. Therefore we need reliable human resources, one of which is millennial generation. Given millennial generation is a generation that grows and develops in the era of technological disruption that is very

* Corresponding author. Email address: novikfbr@gmail.com 
advanced now. So that demands them to be able to compete so they can exist in their lives. Millennial generation is an invaluable asset which if we can process it well it will have a very big impact on changes of company in the future, but if we do not care then it will become a boomerang in the future (Armansyahfudin, 2019). Millennial generation is a large capital that is expected to have superior potential and ability as a driving force for development.

Millennial generation in the world of work according to data from the Central Statistics Agency (BPS) in 2018 recorded millennial occupying the first position with $33.25 \%$ in terms of population composition in Indonesia. Then followed by Generation of Z (29.23\%), Generation of X (25.74\%), and finally baby boomers (11.27\%) (BPS, 2020). These statistics show that the ability to maximize millennial generation and generation $\mathrm{Z}$ is the key to the performance of the Indonesian nation in the future in facing global competition while encouraging productivity growth that impacts the strengthening of the Indonesian economy. Millennial generation along with advances in information, technology and communication are at the forefront of changes in various socio-economic fields. These changes must be quickly anticipated by companies so they can be able to make adjustments to the changes. This has become one of the new challenges for the world of work, because this generation will dominate the world of work (Perdana, 2019).

The characteristics of millennial generation are different from previous generations. Millennials have characteristics that tend to be critical, creative, have a concern for new technology in accordance with world developments, and want the opportunity to have an impact on company or organization (Oktariani et al, 2017). Even this will benefit the company, this generation of thought that thinks outside the box generates creative ideas that are useful for the company's progress. Not surprisingly, many young employees today can occupy high positions in the company. But on the other hand millennial generation also has standards in finding work. Millennials like work that has flexibility both in terms of time and place of work, wants jobs that have meaning as soon as possible, jobs that are challenging and that they think are fun, seek work-life balance and are very enthusiastic about work (Berkup, 2014).

Through the ability of millennial generation as human resources will be able to put the company or organization in a position of competitiveness. Based on the description above, it is clearly implied that excellence in competition is largely determined by, among others, human resource management strategies, especially millennial generation. With the development of appropriate human resource strategies, the superiority of human resources owned by company is expected to support the achievement of competitive advantages of company. Therefore, it has become imperative that we can maximize this millennial generation in order to exist in their work-life, so we must prepare a development strategy that is very useful for them to face their lives, be it in the economic, social, cultural, knowledge, political, and technology.

\section{Literature Study}

\subsection{Human Resources Management}

Human resource management is a comprehensive and coherent approach to employment and development people (Amstrong, 2014). Human resources are the people in the company or organization that contribute ideas and do various types of work in achieving company goals. The intended contribution is the thought and work they do in various activities within the company. In terms of human resources, what is covered is not limited to experts, education staff or experienced personnel, but all the workforce used by the company to realize its goals (Sukirno, 2006). This can be understood because all the company's activities in achieving its goals, depends on the people who manage the company concerned. Therefore, 
human resources must be managed in order to be effective and effective in achieving company goals (Sopiah \& Mamang, 2018). The human resorce management factors consist of as follows (Rivai, 2004):

a. Planning

Human Resource Planning is workforce planning effectively and efficiently to fit with the company's needs and help make it happen company goals.

b. Organizing

Organizing is an activity to organize all employees with a division of labor, employment relations, delegation of authority, integration, and coordination in parts organization.

c. Direction

Directing is an activity that directs all employees to cooperate and work effectively and efficiently in helping the achievement of company, employee and community goals. Direction is done by the leader by assigning subordinates to do all their duties properly.

d. Control

Controlling is all control activities employees to obey company rules and work according to plan. If there are irregularities or mistakes, corrective and refinement measures are taken plan. Employee control includes attendance, discipline, behavior, cooperation, work performance and maintain the work environment situation.

e. Procurement

Procurement is the process of withdrawal, selection, placement, orientation, and induction to get appropriate employees with company needs. Good procurement will help realize the company's goals.

f. Development

Development is a process of increasing skills technical, theoretical, conceptual, and employee morale through education and training. Education and training are given must be in accordance with the needs of today's work and the future. Human resource development is a step continuation of the basic labor supply process aims to ensure and maintain a workforce available, in order to meet the required qualifications and can do work in harmony with strategic planning company, as well as achieving company goals as is planned.

g. Compensation

Compensation is direct and indirect granting of compensation directly, money or goods to employees in return services provided to companies. The principle of compensation is fair and worthy. Fair is interpreted according to achievement it works, is worth interpreting as being able to meet its primary needs and guided by the government minimum wage and based on internal and external consistency.

h. Integration

Integration is an activity to unite the interests of the company and the needs of employees to create harmonious and mutually beneficial cooperation. The company makes a profit, employees can meet the needs and results of their work.

i. Maintenance

Maintenance is an activity to maintain or improve physical, mental, and employee loyalty conditions in order they still want to work together until retirement. Maintenance which is well done with a welfare program based on the needs of most employees as well based on internal and external consistency.

j. Discipline

Discipline is a management function the most important human resource and the key to its realization goals because without discipline it's difficult to realize that goal maximum. Discipline is the desire and awareness for obey company rules and norms social. 
k. Dismissal

Dismissal of employment is a termination of one's employment from the company. Termination is caused by desire employees, company desires, work contracts expire, retirement, and other reasons.

Human resources are a very valuable investment for an organization that needs to be maintained. Each organization must prepare a program that contains activities that can improve the ability and professionalism of human resources so that the organization can survive and develop in accordance with the organizational environment. To achieve maximum productivity, organizations must ensure that the right workforce is chosen with the work and conditions that enable them to work optimally (Hasibuan, 1986). The benefits of developing human resources, namely (Mathis, 2002):

a. Increased work productivity.

b. The realization of a harmonious relationship between superiors and subordinates.

c. The availability of a decision process that is fast and precise.

d. Increased morale of all members in the organization.

e. Encourage management openness attitude.

f. Facilitating effective communication.

g. Functional conflict resolution.

\subsection{Millennial Generation}

Millennial generation is the generation born in the early 1980s to 2000. This generation is often referred to as Gen-Y, Net Generation, WE Generation, Boomerang Generation, Peter Pan Generation, and others. They are called millennial generation because they are the generation that lives at the turn of the millennium. Simultaneously in this era digital technology began to penetrate into all walks of life (Hidayatullah et al, 2018). Generation Y is known as millennial or millennial generation. The phrase generation $\mathrm{Y}$ began to be used in editorials of major US newspapers in August 1993. This generation uses a lot of instant communication technologies such as email, SMS, instant messaging and social media such as Facebook and Twitter, Instagram and others, so in other words generation $\mathrm{Y}$ is generation that grew up in the era of the internet booming (Ahmad et al, 2019).

Based on these definitions, it can be concluded that millennial generation is the generation born between 1980-2000 during the rapid technological progress. When viewed from the age group, millennial generation is the generation that is currently in the age range of 15-34 years. Generation Y has personal abilities or personal above average because they understand the work they are struggling and they are more confident with that ability they have, because of generations millennial is a generation that is live in an age of technology and information that is growing rapidly so they are easily deep finish the work they are do, assisted with abilities communicate good from their personality.

\section{Research Methodology}

This research method used qualitative with research design by library research or literature study. Literature study is a method that uses existing relevant reading sources, which are in line with the topics to be discussed and expanded on understanding (Zed, 2014). The data obtained in this study obtained through library sources or documents. Then the data processing is carried out. Data processing purposes to facilitate the analysis data. The data analysis technique used is analysis descriptive research-related references. Various references that are relevant and tied to the topic presented are used as reading material, to understand carefully the contents of 
the thoughts of the characters whose results are the subject of this paper or a variety of responses and studies that are crucial and important to the results of these thoughts. This paper was developed from a variety of reading sources that are presented with the purposes of answering the formulation of problems regarding the characteristics of millennial generation related to work culture and human resource development strategies for millennial generation.

\section{Results}

\subsection{Development Strategy of Human Resource Management}

To improve human resources to be more effective and efficient, appropriate steps are needed so that the objectives to be achieved can be met. The strategy of developing human resource development is the steps taken so that each individual can be given a method that is in accordance with the capabilities they have, so that he can accept what is given to him to be used as stock to be able to compete in all sectors of life. In human resource management, there are strategies that can be used to improve the development of competencies or abilities for each individual to be able to exist and compete, known as human resource training and development. The various training and development programs are as follows:

a. Training Responsibility (Miftahuddin et al, 2018).

b. Intention to Learn (Armansyahfudin, 2019).

c. Behavior Modification

The following approaches can be taken to achieve these goals, namely as follows: (Perdana, 2019).

1. Positive Reinforcement

2. Negative Reinforcement

d. Immediate Information (Safri, 2019).

e. Learning Practice and Patterns (Farchan, 2018).

Employee performance and productivity is one of the core competencies that must be achieved, where employees not only have skills and experience, but commitments and motivations that are shaped by a good company's culture and climate so that they can support the company's profit growth. The objective of a company in the era of technological disruption is no longer just about profit, but sustainability in the midst of intense competition. The company's success in surviving, even winning business competition becomes the main objective that must be supported and achieved by every element of the company. Competent and superior human resource management, supported by a good company culture and climate, is one of the keys to success, which can be described in the model below (Schneider, Ehrhart and Macey, 2012): 


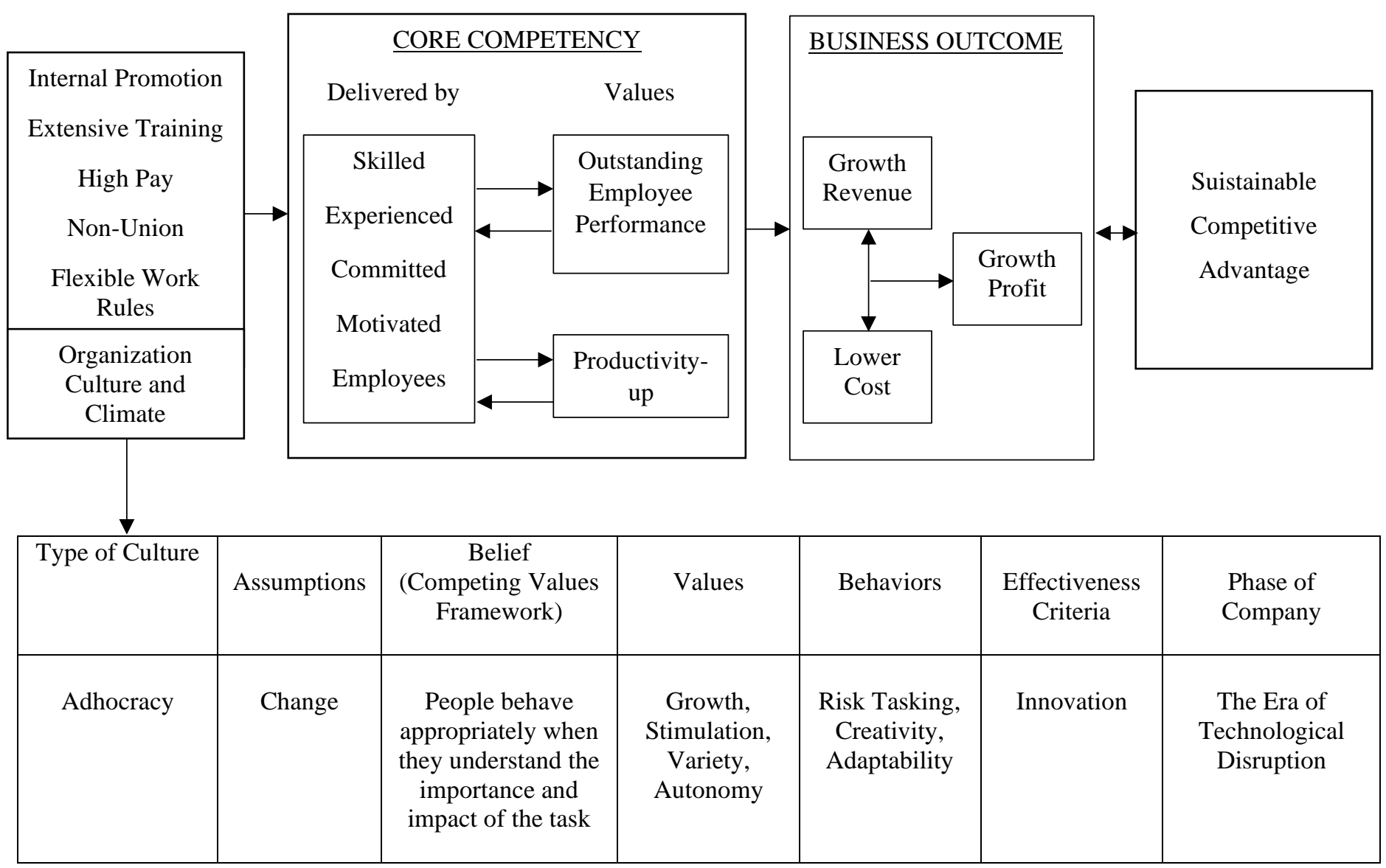

\section{Figure 1 Company Sustainability}

\subsection{Millennial Generation Characteristics Related to Work Culture}

Millennial generation has different characteristics from the previous generation. Millennial generation is concerned about new technology in accordance with world developments. The impact of this generation tends to be more active in trying new things at work. This generation also tends not to be afraid of changes that occur in the company, this makes the millennial generation able to face problems that arise in the work (Oktariani et al, 2017). Millennial generation is more cooperative and optimistic compared to the previous generation and has a high educational background (Yulyanti et al, 2016). However, it cannot be denied that the dependence of millennial generation on technology makes this generation spoiled with such convenience. This condition often leads to the assessment that millennial is an ambitious and arrogant generation. This is a consequence of the mastery of technology owned by millennials so that they can make them competitive in achieving an outcome.

Millennials are also known for their character of being easily bored, having a low tendency towards commitment and loyalty, being less serious and underestimating work (Onibala, 2016). This is because this generation feels that their intelligence is needed by the company. Millennials expect work that has meaning as soon as possible because of their impatient personalities. This generation can easily change jobs (turnover) if the company is not able to give the position they want (Berkup, 2014). In addition to the above characteristics, millennial generation at work has different characteristics compared to previous generations, including (BPS, 2018):

a. Millennial doesn't really pursue job satisfaction, but what millennial wants is the possibility of developing themselves in the job (learning new things, new 
skills, new angles, getting to know more people, taking opportunities to develop, etc.)

b. Millennials do not want a boss who is bossy and controlling.

c. Millennials don't want annual reviews, millennials want on going conversations.

d. Millennials do not think to improve their shortcomings, millennials think more about developing their strengths.

e. Millennials consider compensation in choosing work.

f. Millennial generation also prioritizes the value of a balance between work and personal life (work-life balance).

g. The verbal communication behavior of millennial generation which is open, frontal, and confrontational.

Table 1 Intergenerational characteristics (Anantatmula \& Shrivastav, 2012)

\begin{tabular}{|c|c|c|c|}
\hline Period & Baby Boomers & Gen-X & Gen-Y (Millennial) \\
\hline Workplace Traits & $\begin{array}{c}\text { Team orientation, } \\
\text { optimistic, loyal, } \\
\text { hard working }\end{array}$ & $\begin{array}{c}\text { Practical, } \\
\text { pessimist, work } \\
\text { life balance, } \\
\text { technical, } \\
\text { independent, be } \\
\text { adapted }\end{array}$ & $\begin{array}{c}\text { Ambitious, trust selft, } \\
\text { work } \\
\text { life balance, multi } \\
\text { tasking, } \\
\text { independent }\end{array}$ \\
\hline Leadership style & $\begin{array}{c}\text { Influencing, } \\
\text { mentoring }\end{array}$ & $\begin{array}{c}\text { Practical, goal } \\
\text { oriented }\end{array}$ & $\begin{array}{c}\text { Flexible, lack of } \\
\text { social grace }\end{array}$ \\
\hline Motivation & $\begin{array}{c}\text { Ability, bonuses, } \\
\text { incentives, } \\
\text { contribution }\end{array}$ & $\begin{array}{c}\text { Time-off as } \\
\text { incentive }\end{array}$ & $\begin{array}{c}\text { Higher position, } \\
\text { monetary gains, } \\
\text { lower need for } \\
\text { social approval }\end{array}$ \\
\hline Learning sytle & $\begin{array}{c}\text { Clasroom, } \\
\text { instructure- } \\
\text { focused }\end{array}$ & $\begin{array}{c}\text { Technology focus, } \\
\text { mentors }\end{array}$ & $\begin{array}{c}\text { Creative thinking, } \\
\text { visual }\end{array}$ \\
\hline
\end{tabular}

\section{Discussion}

The role of human resources in companies can be elaborated in terms of human resource theory, where the function of the company or organization is to mobilize all resources or internal capabilities to face market interests as the main external factor. Whatever its shape and purpose, a company is created based on various visions for human interests and in the implementation of its mission is managed and managed by humans. Thus, humans are a strategic factor in all institutional or organizational activities. furthermore, human resource management means managing, managing human resources based on the company's vision so that organizational goals can be achieved optimally.

Human resource management is a comprehensive and coherent approach to employment and development people (Amstrong, 2014). Human resources are the people in the company or organization that contribute ideas and do various types of work in achieving company goals. The intended contribution is the thought and work they do in various activities within the company. In terms of human resources, what is covered is not limited to experts, education staff or experienced personnel, but all the workforce used by the company to realize its goals (Sukirno, 2006). The main objective of human resource management is to increase the contribution of employees to the company or organization in order to achieve the productivity of the organization 
concerned. This can be understood because all the company's activities in achieving its goals, depends on the people who manage the company concerned.

Therefore giving effective development strategy and efficient especially for generations millennial now is a which must be done. Remembering millennial generation is a generation that is grow and develop in the era very advanced technology now this. Millennial generation is the generation born in the early 1980s to 2000. This generation is often referred to as Gen-Y, Net Generation, WE Generation, Boomerang Generation, Peter Pan Generation, and others. They are called millennial generation because they are the generation that lives at the turn of the millennium. Simultaneously in this era digital technology began to penetrate into all walks of life (Hidayatullah et al, 2018). Generation $Y$ has personal abilities or personal above average because they understand the work they are struggling and they are more confident with that ability they have, because of generations millennial is a generation that is live in an age of technology and information that is growing rapidly so they are easily deep finish the work they are do, assisted with abilities communicate good from their personality.

Millennial generation has different characteristics from the previous generation. Millennial generation is concerned about new technology in accordance with world developments. The impact of this generation tends to be more active in trying new things at work. This generation also tends not to be afraid of changes that occur in the company, this makes the millennial generation able to face problems that arise in the work (Oktariani et al, 2017). Millennial generation is more cooperative and optimistic compared to the previous generation and has a high educational background (Yulyanti et al, 2016). However, it cannot be denied that the dependence of millennial generation on technology makes this generation spoiled with such convenience. This condition often leads to the assessment that millennial is an ambitious and arrogant generation. This is a consequence of the mastery of technology owned by millennials so that they can make them competitive in achieving an outcome.

Millennials are also known for their character of being easily bored, having a low tendency towards commitment and loyalty, being less serious and underestimating work (Onibala, 2016). This is because this generation feels that their intelligence is needed by the company. Millennials expect work that has meaning as soon as possible because of their impatient personalities. This generation can easily change jobs (turnover) if the company is not able to give the position they want (Berkup, 2014). In addition to the above characteristics, millennial generation at work has different characteristics compared to previous generations, including (BPS, 2018):

a. Millennial doesn't really pursue job satisfaction, but what millennial wants is the possibility of developing themselves in the job (learning new things, new skills, new angles, getting to know more people, taking opportunities to develop, etc.)

b. Millennials do not want a boss who is bossy and controlling.

c. Millennials don't want annual reviews, millennials want on going conversations

d. Millennials do not think to improve their shortcomings, millennials think more about developing their strengths.

e. Millennials consider compensation in choosing work.

f. Millennial generation also prioritizes the value of a balance between work and personal life (work-life balance).

g. The verbal communication behavior of millennial generation which is open, frontal, and confrontational.

With behaviors that prioritize applicable processes and technology, millennials are willing to contribute more and extra work hours but they are sensitive to personal time related to hobbies. Specifically millennials like work environments that have (a) clarity in their duties and responsibilities to manage work rhythm (b) time flexibility (c) comfortable work environment (d) opportunities to develop themselves according to aspirations and (e) challenges in profession (Paramitha \& Ihalauw, 2018). This actually makes this generation more exploratory and has the intuition and courage to 
speak. But this behavior is also often misinterpreted by previous generations as a form of immaturity or immodesty (Saragih et al, 2016).

The characteristics of millennial generation show the opportunity for the development of mind sets as the workforce is so focused and structured. This requires several strategies for developing human resource management. To improve human resources to be more effective and efficient, appropriate steps are needed so that the objectives to be achieved can be met. The strategy of developing human resource development is the steps taken so that each individual can be given a method that is in accordance with the capabilities they have, so that he can accept what is given to him to be used as stock to be able to compete in all sectors of life. In human resource management, there are strategies that can be used to improve the development of competencies or abilities for each individual to be able to exist and compete, known as human resource training and development. The various training and development programs are as follows:

a. Training Responsibility

In increasing the competency of each individual responsible training is something that must be done. People who can take responsibility for their actions and take responsibility for their actions are only those who make decisions and act without pressure from any party or freely. Training is carried out so that having a sense of responsibility must be carried out since they join a company or organization (Miftahuddin et al, 2018).

Millennials are people who have extraordinary talent because they are developing in the world of advanced technology. Therefore they will easily be able to adjust the work they will do. Millennials are individuals who must be trained to have a high sense of responsibility. The process of developing a sense of responsibility for the millennial generation can be done by giving confidence to them to hold a position or job that requires them to be able to provide maximum results about the results of the position they hold or the work they do. A leader who has given responsibility to a millennial generation to hold a position must be able to set an example and control that individual so that the tasks and responsibilities that are given can be completed quickly and precisely according to the goals and ideals to be achieved.

b. Intention to Learn

Intensive learning must be given to millennials. Because with intensive learning (intention to learn) will increase the skills and abilities of each individual. Intensive learning in an institution or company is a training that is given regularly and continuously in order to maintain the existence and hone the skills possessed to be better. Improving the ability of self for each individual belonging to the millennial generation is a must and is very necessary, because the competition that occurs in the world of work is very tight and competitive (Armansyahfudin, 2019).

So for millennials who do not have abilities above the average will be easily excluded and will not be able to compete. Therefore intensive learning that is given through structured and ongoing training such as giving seminars and workshops in accordance with the qualifications of the knowledge they have or the work that is being done is a very useful step. So that the goals or ideals of a company or organization will be very easily achieved, because it has quality and reliable human resources.

c. Behavior Modification

Every work carried out by the millennial generation is very easily accomplished by them because they have an understanding of the structure in which they work and what systems help them. Modifying behavior is an attempt to change human behavior and emotions in a way that is advantageous based on the laws of modern learning processes. Behavior modification is an attempt to increase competitiveness or ability for each individual. The following approaches can be taken to achieve these goals, namely as follows (Perdana, 2019):

a) Positive Reinforcement

The first approach is positive reinforcement. This approach will pair positive stimulus with behavior. This technique is very commonly done by strengthening 
behavior using a reward system. A leader who often gives rewards to every individual, especially the millennial generation will motivate the individual to continue to exist. Because millennial generation is a generation that really needs respect for themselves. So that being given an award will increase their trust and existence to be higher.

b) Negative Reinforcement

Contrary to the previous point about positive reinforcement, the second approach is negative reinforcement. This approach is a couple between certain behaviors and negative stimulus removal. This method will provide training on the subject of behavior using amplifiers that are negative. With this negative reinforcement, the behavior will be tried to be eliminated. One example of negative reinforcement is the application of disciplinary action by supervisors to make employees make sure their work is on target. In this case, disciplinary action is a negative reinforcement and completing work according to target is the expected behavior.

d. Immediate Information

The next strategy is immediate confirmation, which is a situation in which a person is demanded to be able to provide accurate and correct information in accordance with what can or can be heard or obtained from the field. How to confirm a job or information that is not in accordance with the events that occur will result in chaos in a company or organization. So the emphasis on confirming a truth must be instilled in each individual. For millennials who live in the era of technological disruption, confirming a truth is a must. Therefore honesty for millennial generation is very expensive (Safri, 2019).

e. Learning Practice and Patterns

For millennial generation practices and learning patterns are demanded to be more varied. So that through practice and varied learning patterns will produce quality abilities and skills. In developing self ability, millennial generation must be demanded to carry out more practices in the field to produce superior individuals. One of the practices that can be done is On the Job Training. On the Job Training or also referred to as training with job instructions as a method of training by means of workers or prospective workers placed in real work conditions, under the guidance and supervision of experienced employees or a supervisor. Next practice that can be done is an internship. Internships involve learning from more experienced workers, and can be added to the Off the Job Training technique. Many workers skills are trained through official apprenticeship programs (Farchan, 2018).

Employee performance and productivity is one of the core competencies that must be achieved, where employees not only have skills and experience, but commitments and motivations that are shaped by a good company's culture and climate so that they can support the company's profit growth. The objective of a company in the era of technological disruption is no longer just about profit, but sustainability in the midst of intense competition. The company's success in surviving, even winning business competition becomes the main objective that must be supported and achieved by every element of the company (Vittal and Bobby, 2012). Competent and superior human resource management, supported by a good company culture and climate, is one of the keys to success.

Sustainable strategies in developing human resource management for millennial generation can be done with a model of ability, motivation and opportunity. Ability, namely the ability to perform tasks because they have knowledge, work abilities or skills, and talents. Motivation, which is the desire to do the task of one's own desire or feel compelled to do the task. Opportunity, which is a work structure and a supportive environment and a place to express oneself. The combination of the three strategies will support and spur employees to bring out the best potential in work so as to increase work productivity. This will have an impact on the company's revenue growth and lower costs. Revenue growth and cost reduction will have an impact on profit growth 
in line with the company's long-term sustainability.

\section{Conclusion}

Development strategy of human resource management for millennial generation is a step purposed at producing superior individuals who have characteristics and abilities that can compete and have a sale value that can be relied on either in a company or organization. The strategy being carried out is a way to improve the ability of every individual likes a training responsibility, intensive learning, behavior modification, immediate information, learning practice and patterns. Supporting sustainable factors are ability, motivation and opportunity. Planning a good human resource development strategy in developing strategies to produce quality human resources is a necessity that is the duty of every company or organization leader to achieve the goals set. Therefore we need reliable human resources, one of which is millennial generation. The development strategy that has been analyzed is a strategy that can be used in order to develop interpersonal skills for millennial generation.

\section{References}

Ahmad, W, et al. (2019). Potret Generasi Millennial Pada era Revolusi Industri 4.0. Focus: Jurnal Pekerjaan Sosial, 2(2), 187-197.

Amstrong, M. (2014). Handbook of Human Resource Management. United Kingdom: Kogan Page.

Anantatmula, V. S., \& Shrivastav, B. (2012). Evolution of Project Teams for Generation Y Workforce. International Journal of Managing Projects in Business, 5(1), 13.

Armansyahfudin. (2019). Strategi Pengembangan Manajemen Sumber Daya Manusia Bagi Generasi Millenial. Nidhomul Haq: Jurnal Manajemen Pendidikan Islam, 4(2), 169-185.

Badan Pusat Statistik. (2018). Statistik Gender Tematik: Profil Generasi Milenial Indonesia. Jakarta: Kementrian Pemberdayaan Perempuan dan Perlindungan Anak.

Badan Pusat Statistik. (2020). Sensus Penduduk 2020, Sensus Era Digital. Accessed From https://bps.go.id/news/2020/01/07/15/sensus-penduduk-2020--sensus-eradigital---.html.

Berkup, S. B. (2014). Working with Generations X and Y in Generation Z period: Management of Different Generations in Business Life. Mediterranean Journal of Social Sciences, 5(19), 223.

Farchan, F. (2018). Strategi MSDM Sebuah Cara Menciptakan Kinerja Organisasi Dalam Mencapai Keunggulan Bersaing. Risalah: Jurnal Pendidikan dan Studi Islam, 4(1), 42-52.

Hasibuan, M. S. P. (1986). Managemen dasar, Pengertian dan Masalah. Jakarta: Gunung Agung.

Hidayatullah, S, et al. (2018). Perilaku Generasi Millennial dalam menggunakan Aplikasi Go-Food. Jurnal Manajemen dan Kewirausahaan, 6(2), 240-249. 
Mathis, R. L. (2002). Human Resources Management. Jakarta: Salemba Empat.

Miftahuddin, et al. (2018). Strategi Pengembangan Sumber Daya Manusia. Tadbir: Jurnal Manajemen Dakwah, 3(2), 01-16.

Oktariani, D, et al. (2017). Kepuasan Kerja Generasi X dan Generasi Y terhadap Komitmen Kerja di Bank Mandiri Palembang. Jurnal Aplikasi Bisnis dan Manajemen, 3(1), 12-22.

Onibala, T. (2016). Karakteristik Karyawan Generasi Langgas Menurut Pandangan Para Pemimpin. Confererence on Management and Behavioral Studies. Jakarta: Universitas Tarumanegara.

Paramitha, Y., \& Ihalauw, J. J. O. I. (2018). Persepsi Generasi Y Mengenai Pekerjaan, Komitmen Kerja, dan Keberlanjutan Kerja. Journal of Business and Applied Management, 11(2), 215.

Perdana, P. K. (2019). Generasi Milenial dan Strategi Pengelolaan SDM di Era Digital. Jurnal Studi Pemuda, 8(1), 75-80.

Rivai, V. (2004). Managemen Sumber Daya Manusia Untuk Perusahaan Dari Teori Ke Praktek. Jakarta: PT. Raja Grafindo Persada.

Safri, H. (2019). Manjemen Sumber Daya Manusia Global. Informatika: Jurnal Ilmiah AMIK Labuhan Batu, 7(1), 1-16.

Saragih, et al. (2016). Big City Millenial Workers in Indonesia and Factors Affecting Their Commitment to the Organisation. Pertanika Journal 24 (S), 53.

Schneider, B., Ehrart, M.G., \& Macey, W. H. (2013). Organizational Climate and Culture. Journal of AZ (Annual Reviews). 7(63), 361-388.

Sopiah., \& Mamang, E. (2018). Manajemen Sumber Daya Manusia. Yogyakarta: ANDI Offset.

Sukirno, S. (2006). Pengantar Bisnis. Jakarta: Prenada Media Group.

Yulyanti, T, et al. (2016). Persepsi Kondisi Kerja dan Kinerja Karyawan Generasi Y. Manajemen IKM, 11(2), 111-122.

Zed, M. (2014). Metode Penelitian Kepustakaan. Jakarta: Yayasan Pustaka Obor Indonesia. 